\title{
Definition of Hay Eating and Rumination Period and Analysis of Relationship between Eating and Rumination Activities in Steers Fed Hay ad libitum
}

\author{
Shigeru Morrta and Susumu Nishino \\ Department of Dairy Science, Rakuno Gakuen \\ University, Ebetsu-shi 069
}

(Received May 17, 1993)

\begin{abstract}
Sixteen Holstein steers, five months old, were used to define eating and rumination periods and to study the relationship between eating and rumination activity in steers fed hay ad libitum with a restricted quantity of concentrate. About $75 \mathrm{~g}$ dry matter (DM) of concentrate were offered per $\mathrm{kg}$ metabolic body size (MBS). The amount of long hay offered was more than $110 \%$ of intake. The total time spent on eating bouts of hay was 210 minutes. The distribution of the length of hay eating bouts fitted into a random distribution. The breakpoint of distribution of intervals between eating bouts was determined to be 4 minutes. We concluded that a meal was defined as eating activity occurring after at least 4 minutes of no eating activity. The distribution of rumination bout-length also fitted into the random distribution. The breakpoints of the distribution of interval between rumination bouts were determined to be 2 and 15 minutes. Rumination period was defined as rumination activity occurring after at least 15 minutes of no rumination activity. Correlation coefficients between the pre-meal interval length and the meal length were positive $(\mathrm{P}<0.05)$ in periods 3 hours after a feeding to the next. The correlation coefficient between time spent on rumination periods and on the following meals was positive. We concluded that the time spent on meals after the onset of rumination was affected by the time spent on rumination periods before meal. It is suggested that if time spent on rumination period is restricted by some factors, the time spent on meals might be shortened.
\end{abstract}

Anim. Sci. Technol. (Jpn.) 65 (9) : 796-805, 1994

Key words : Bout length, Interval length, Meal, Rumination period, Steers

Successful animal production is greatly dependent on the amount of feed intake. Generally, eating behavior changes with the amount of intake. It is, therefore, important to study the eating behavior of animals.

The eating period (meal) consists of actual eating (eating bouts) and short non-eating periods (within-meal intervals) ${ }^{2)}$. These eating periods are separated by long non-eating periods (inter-meal intervals). There are, however, no reports that defined a meal or inter-meal interval in ruminants by stochastic method, except for that of METz in which cows were offered hay wafer ad libitum. Thus, the definition for a meal of ruminants has been inconsistent among studies on eating behavior ${ }^{3,4,10,11)}$. The definition should be considered stochastically.

There are numerous reports in which meals were defined by the distribution of intervals between eating bouts in non-ruminants ${ }^{5,12,15)}$. In these reports, meal length or meal size (amount of intake per meal) are related to the length of an inter-meal interval that is pre- 
ceded by a meal, but they do not relate to the interval that is followed by a meal ${ }^{5,12,15)}$. WANGNESS et $a l^{14)}$ concluded that meal size did not relate to the pre- and post-meal intervals in steers. METz $z^{7)}$ indicated that meal length should be related to the pre-meal interval, but not to the post-meal interval.

Differing from non-ruminants, ruminants have developed rumination activity, which is a special adaptation for remasticating digesta. It seems that the length of inter-meal interval that consists rumination periods is related to meal length. There is a time lag after eating to the start of rumination periods ${ }^{8}$. A study of the diurnal pattern of meals and rumination periods is necessary in order to analyze the relationship between meal and inter-meal interval length.

In this study, we tried to define meals and rumination periods by examining the distribution of interval length between eating and rumination bouts. Based on this definition, we analyzed the diurnal pattern of meals and rumination periods in order to find a possible trigger for the onset of eating and rumination activities in steers.

\section{Materials and Methods}

Sixteen Holstein steers, approximately five months old and weighing, on average, $200 \mathrm{~kg}$ were used at the start of this study. The steers were offered pelleted concentrate in a trough and long hay on a hay rack twice daily $(8: 20$ and $17: 20)$ simultaneously, without mixing their diets. The chemical compositions and energy content of the concentrate and hay are shown in Table 1.
Each steer was offered about $75 \mathrm{~g}$ of pelleted concentrate on a DM basis per kg MBS and long hay over $110 \%$ of the amount of intake on an air-dry matter basis. The experimental periods lasted 11 days for each steer. On the last day of experimental period, the starting and ending time for hay eating were recorded using a video recorder. Hay eating bout started as of the time the steers started moving their jaw to eat. Eating bout ended when they stopped chewing and swallowing the very last bolus. Eating bout was not defined as having stopped when the steers started chewing within 5 seconds after swallowing.

The number $\left(\mathrm{N}_{\mathrm{i}}\right)$ of eating bouts and intervals between eating bouts that length was longer than $t_{i}$ was determined by the following exponential equation, in which $\mathrm{N}_{0}$ is the total number of eating bouts or intervals.

$$
\mathrm{N}_{\mathrm{i}}=\mathrm{N}_{0} \exp \left(-\mathrm{b}_{\mathrm{i}} \mathrm{t}_{\mathrm{i}}\right)
$$

If the distribution of the length of eating bouts fits into this theoretical exponential equation (random distribution), the percentage of $\mathrm{N}_{\mathrm{i}}$ to $\mathrm{N}_{0}$ (cumulative frequency) is expressed as $100 \exp \left(-b_{i} t_{i}\right)$. When the relationship between eating bout length or interval length and the natural logarithm of cumulative frequency (log survivor function) is linear, $b_{i}$ is single phase. When the sample distribution did not fit into the random distribution according to the Kolmogorov-Smirnov one-sample test $^{13)}$, the eating bouts and intervals between eating bouts were divided by their length to fit into the random distribution. A meal and inter-meal interval were defined from the distribution of length of eating bouts and intervals between eating bouts.

Table 1. Chemical composition and gross energy content of diet

\begin{tabular}{lccccc}
\hline & Dry Matter & $\mathrm{CP}^{1}$ & $\mathrm{NDF}^{2)}$ & $\mathrm{ADF}^{3)}$ & $\mathrm{GE}^{4}$ \\
\hline \multirow{3}{*}{ Concentrate } & 86.3 & 17.1 & 19.7 & 7.8 & MJ/kg DM \\
Hay & 87.0 & 9.8 & 71.5 & 44.2 & 18.6 \\
\hline
\end{tabular}

1) Crude Protein, ${ }^{2)}$ Neutral Detergeni Fiber, ${ }^{3)}$ Acid Detergent Fiber,

4) Gross Energy. 
Chewing activity was recorded by an electromyogram measurement on the last day of the experimental period, simultaneously with eating behavior recording by video. During rumination activity, chewing was characterized by a pause between swallowing one bolus and regurgitating the next. The average time taken for each pause was about 5 seconds $^{8)}$ or about 10 seconds $^{9)}$. A rumination cycle is one complete act of rumination, consisting of regurgitation, remastication and reswallowing. In this study, rumination bout (an uninterrupted series of rumination cycle) defined as rumination activity separated by at least 15 seconds of no rumination. The distribution of the length of rumination bouts and intervals between rumination bouts was compared with the random distribution in the same way as for examining the distribution of the length of eating bouts and intervals between eating bouts.

\section{Results and Discussion}

Table 2 shows the DM intake of hay and the time spent on eating bouts. The amount of DM intake of hay per MBS was approximately $28 \mathrm{~g} / \mathrm{kg}^{0.75} /$ day. The daily time spent on eating bouts was 210 minutes. The rate of eating calculated from eating bout was 7.8 gDM/minute. CHASE et al. ${ }^{1)}$ reported that the average DM intake was $114 \mathrm{gDM} / \mathrm{kg}^{0.75} /$ day. In their study, steers were fed a mixed ration containing $28.4 \%$ chopped hay. In this study, the concentrate was fed separately and restrictively, and the amount was $75 \mathrm{gDM}$ / $\mathrm{kg}^{0.75} / \mathrm{day}$. The percentage of hay intake in

Table 2. Hay intake and time spent on eating bouts of steers

\begin{tabular}{lcc}
\hline & Average & S.E. \\
\hline Hay intake $\left(\mathrm{DMg} / \mathrm{kg}^{0.75} /\right.$ day) & 27.6 & 1.4 \\
$\begin{array}{l}\text { Time spent eating bouts } \\
\text { (min./day) }\end{array}$ & 208 & 15 \\
Rate of eating (DMg/min.) & 7.8 & 0.7 \\
\hline
\end{tabular}

1) Standard Error. this study (27\% hay) was approximately the same as the study reported by CHASE et al. ${ }^{1}$. The total DM intake was about $100 \mathrm{gDM} / \mathrm{kg}^{0.75}$ / day. This was approximately equal to the amount of the study reported by CHASE et al. ${ }^{11}$.

Figure 1 shows the distribution of length of eating bouts and intervals between eating bouts. The distribution of length of eating bouts fits into the random distribution. $\mathrm{METz}^{7)}$ observed that the distribution of length of eating bouts in cows fed hay wafer under $a d$

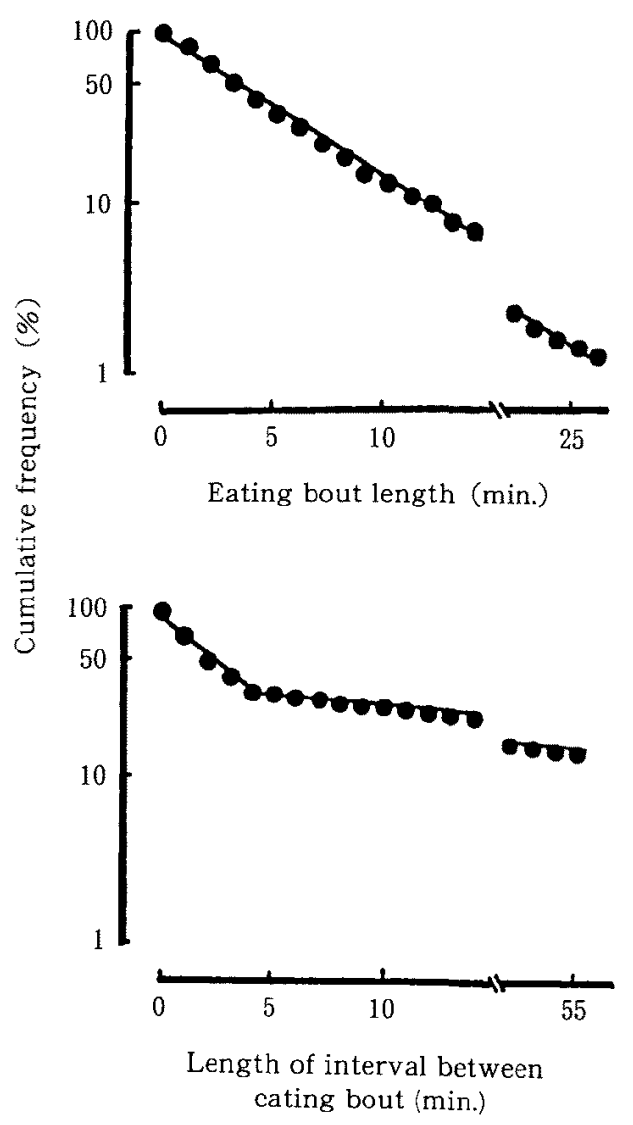

Fig. 1. Log survivor functions for length of eating bout $(n-665)$ and of interval between eating bout ( $\mathrm{n}=633$ ) in steers. Each point gives the percentage of eating bouts and intervals longer than the length shown on the abscissa. The straight line indicates the random distribution. Two random distributions were used for intervals, one is equal and shorter than 4 minutes, other is longer than 4 minutes. 
libitum feeding conditions fitted into the random distribution regardless of eating bout length. The eating bout distribution results in this study agree with the study reported by

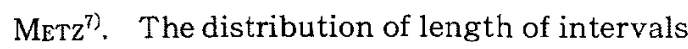
between eating bouts did not fit into the random distribution when all results were used. The breakpoint of distribution of intervals between eating bouts was determined to be 4 minutes. The distribution of length of intervals between eating bouts that were 4 minutes or less and intervals that were longer than 4 minutes fitted into the random distribution.

$\mathrm{METZ}^{7)}$ defined meals as eating periods separated by at least 20 minutes of no eating activity. In the study reported by $\mathrm{METZ}^{7)}$, there were breakpoints in the distribution of intervals between eating bouts at 4 and 20 minutes. In this study, the only breakpoint in the interval distribution was at 4 minutes, not at 20 minutes. When we determined meals according to the results obtained by $\mathrm{METZ}^{\text {?) }}$, some rumination periods occurred within meals. This indicated that the meal definition postulated by METz ${ }^{7)}$ was not good for analysis showing the relationship between meals and rumination periods. Therefore, we concluded that intervals longer than 4 minutes were inter-meal intervals and that a meal was, thus, defined as eating activity occurring at least 4 minutes after no eating activity.

Figure 2 shows the distribution of length of rumination bouts and intervals between

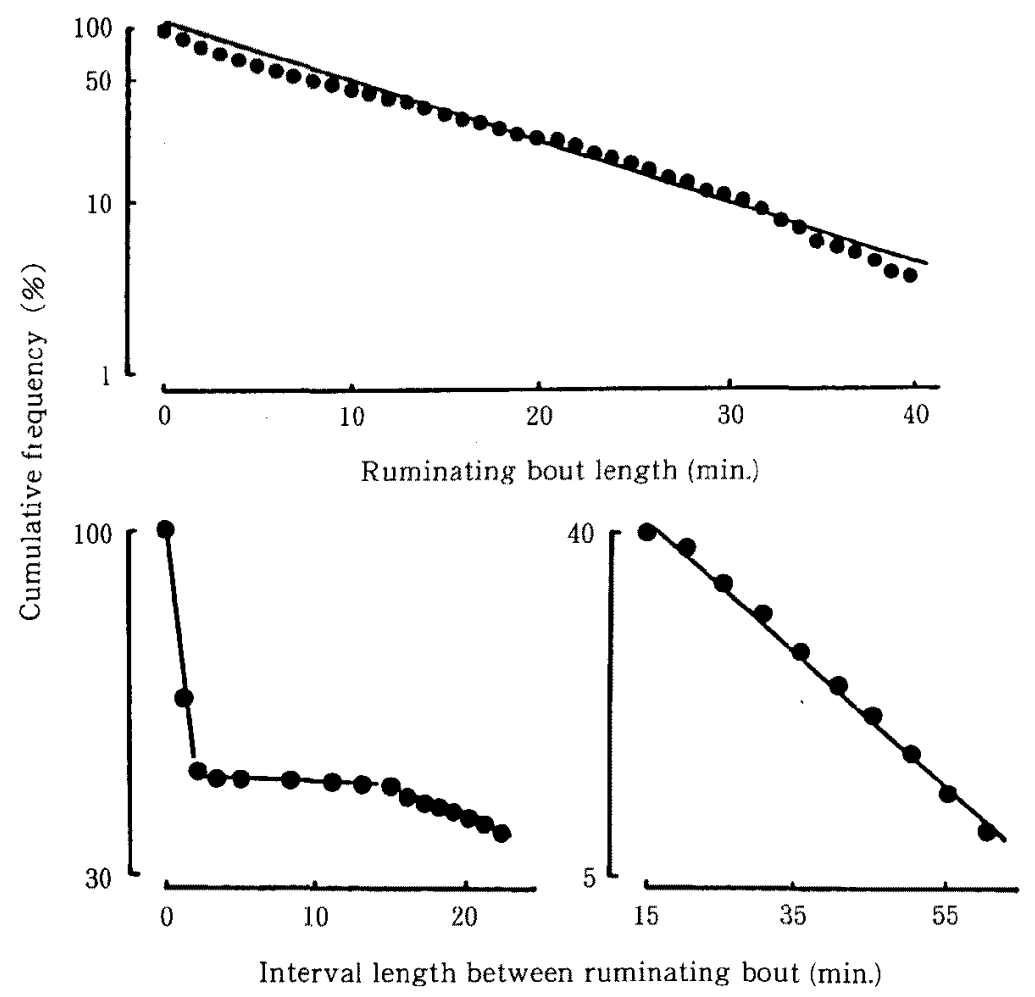

Fig. 2. Log survivor functions for length of rumination bout $(n=488)$ and of interval between rumination bouts $(n=456)$ in steers. Each point gives the percentage of rumination bouts and intervals longer than the length shown on the abscissa. The straight line indicates the random distribution. Three random distributions were used for intervals. 
rumination bouts. The distribution of length of rumination bouts fitted into the random distribution. The distribution of length of intervals between rumination bouts did not fit into the random distribution when all results were used. The breakpoints of the interval distribution were determined to be 2 and 15 minutes. We defined rumination period as rumination activity occurring at least 15 minutes after no rumination activity. Intervals that were less than 2 minutes were within-bout intervals, that is, pauses between the swallowing of one bolus and regurgitation of the next.

Table 3 shows the daily time spent on meals, number of meals, average meal length and the percentage of time spent on eating bouts during meals. The time spent on meals was 242 minutes/day, and the daily number of meals was about 15 . The average meal length was 17 minutes and the percentage of time spent on eating bouts during meals was approximately $86 \%$. Thus, one meal consisted of a 15-minute eating bout and a 2-minute within-meal interval.

CHASE et al. ${ }^{1)}$ concluded that the daily time actually spent eating was about 156 minutes, and that the number of meals was 10 . The time actually spent eating was defined merely as active eating time, and was the same as the time spent on eating bouts in this study. From their results, the time actually spent eating per meal was 15.6 minutes. They fed cattle a mixed ration and recorded eating behavior. In this study, we recorded hay eating behavior. These results suggested that time spent on eating bout per meal was about

Table 3. Time spent on meals and average meal length in steers

\begin{tabular}{lcc}
\hline & Average & S.E. ${ }^{1)}$ \\
\hline Time spent meals (min./day) & 242 & 18 \\
No. of meals & 14.7 & 0.8 \\
Meal length (min.) & 17.4 & 1.7 \\
Bout/Meal (\%) & 86.4 & 1.7 \\
\hline
\end{tabular}

1) Standard Error. the same, regardless of diets offered. Even though daily amount of DM intake (Table 2) and time spent on eating bouts per meal are about the same, it dose not always mean that diurnal pattern is similar in meal eating behavior. The analysis of diurnal pattern of eating and rumination activities is more important than day-base results. Thus, we analyzed the relationships between eating and rumination activity, in order to find a possible trigger for the onset of eating and rumination activities in steers.

The result of meal frequency would have differed due to the different definition of meal. The average number of meals per day was 10 in the study reported by CHASE $e t a l .^{1}$, and ranged from 6 to 11 in adult cows fed hay wafers ${ }^{7}$. They defined a meal as eating activity occurring at least 20 minutes after no eating activity. This is why the number of meals in this study was higher than in other reports ${ }^{1.7)}$.

Figure 3 shows the diurnal distribution of time spent on meals and on rumination periods per one hour. The time spent on meals within 3 hours after hay feeding was longer than for other cases, with some hay still available in the hay rack. The time spent on rumination periods within 3 hours was shorter than for other cases.

Table 4 shows the latent period of rumination activity (time from feeding to starting of first rumination). The latent period of rumination activity was about 2.8 hours, and was the same for both morning and afternoon feedings. After the onset of rumination, the time spent on meals decreased and time spent on rumination periods increased.

Since the time spent on meals was longer and the time spent on rumination periods was shorter within 3 hours after hay feeding than in other periods (Fig. 3), diurnal analysis was conducted over four periods, from $8: 20$ to 11 : 19 (period 1), $11: 20$ to $17: 19$ (period 2), $17: 20$ to $20: 19$ (period 3) and from $20: 20$ to $8: 19$ on the next day (period 4). Table 5 shows the 


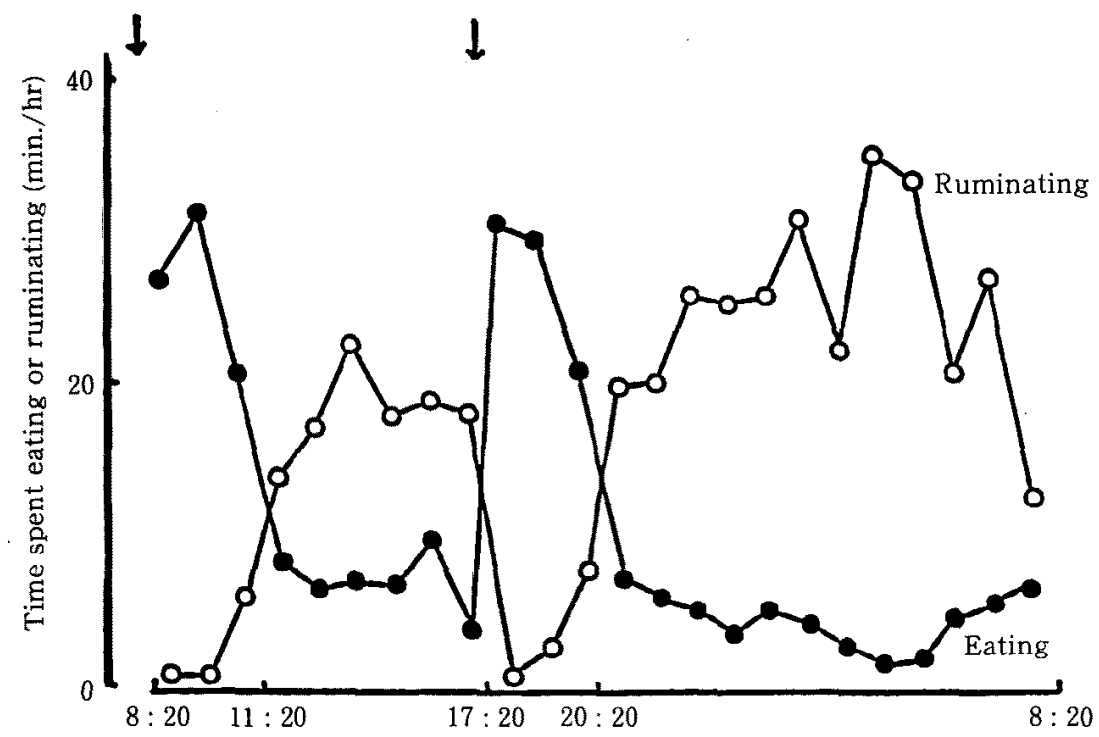

Fig. 3. Diurnal changes in the time spent on meal and rumination. Arrows represent the time of feeding.

Table 4. Latent period ${ }^{1)}$ of rumination activity

\begin{tabular}{lcc}
\hline \hline & Average & S.E. \\
\cline { 2 - 3 } & 2.8 & \\
Morning $^{3)}$ & 2.8 & 0.3 \\
Afternoon $^{3)}$ & 0.2 \\
\hline
\end{tabular}

1) Period from morning and afternoon diet offered to onset of rumination.

2) Standard Error.

3) Feeding time was $8: 20$ (morning) and $17: 20$ (afternoon).

diurnal variation in meal and inter-meal interval length. The meal length tended to be longer in periods 1 and 3 than in periods 2 and 4. HAYASAKA et al. ${ }^{3)}$ pointed out that meal length that occurred immediately after feeding was longer than others. The results of this study agree with their result. The inter-meal interval length in periods 1 and 3 was significantly $(\mathrm{P}<0.05)$ shorter than in periods 2 and 4 , and was significantly $(P<0.05)$ longer in period 4 than in period 2. The number of meals did not differ among periods. The latent period of rumination after offering hay was about 2.8 hours in this study. The results
Table 5. Meal and inter-meal interval length in each period

\begin{tabular}{lrr}
\hline & Average & S.E. \\
\hline Meal length (min.) & & \\
Period $1(8: 20 \sim 11: 19)$ & $21.5^{\mathrm{a}}$ & 3.0 \\
Period 2 $(11: 20 \sim 17: 19)$ & $12.1^{\mathrm{b}}$ & 1.4 \\
Period 3 $(17: 20 \sim 20: 19)$ & $27.7^{\mathrm{a}}$ & 3.3 \\
Period $4(20: 20 \sim 8: 19)$ & $12.2^{\mathrm{b}}$ & 1.2 \\
Inter-meal interval length (min.) & & \\
Period 1 & $29.1^{\mathrm{a}}$ & 5.3 \\
Period 2 & $74.0^{\mathrm{b}}$ & 12.0 \\
Period 3 & $24.7^{\mathrm{a}}$ & 2.6 \\
Period 4 & $192.7^{\mathrm{c}}$ & 17.0 \\
Number of meals & & \\
Period 1 & 3.9 & 0.3 \\
Period 2 & 4.4 & 0.5 \\
Period 3 & 3.8 & 0.3 \\
Period 4 & 3.9 & 0.4 \\
\hline
\end{tabular}

1) Standard Error.

$a, b, c$ Differences between averages with a different letter are statistically significant $(P<0.05)$.

of this study show that there are remarkable changes of meal and inter-meal interval length between the period within 3 hours and the period 3 hours after feeding, that is, between 
the periods before and after the onset of rumination activity, but no changes in number of meals. If meal length changed with the length of the rumination periods in pre-meal interval, it is necessary to extend the rumination period for the improvement of roughage intake in the period after the onset of rumination activity.

Table 6 shows the length of rumination periods and interval between rumination periods. The length of rumination period was longer in period 4 than in other periods. The interval between rumination periods tended to be longer in periods occurring immediately after feeding (periods 1 and 3 ) than in periods 2 and 4. The number of ruminations in periods 1 and 3 was significantly $(P<0.05)$ lower than in period 2, while that in period 4 was significantly $(\mathrm{P}<0.05)$ higher than those in other periods. In periods 1 and 3 , meal length and time spent on meals were long, and hardly did any rumination activity occur. In this study, therefore, results obtained after onset of rumination were analyzed with reference to time spent on meal to clarify the relationship between eating and rumination activities.

Table 7 shows the correlation coefficient among meal length, pre- and post-meal interval lengths. In all periods, the correlation coefficients between the post-meal interval length and meal length were not significant. The correlation coefficients between the pre- meal interval length and meal length were positive $(\mathrm{P}<0.05)$ in periods 2 and 4 , but were not significant in periods 1 and 3 . These results suggested that hay intake may increase as the meal length increases with the extension of the pre-meal interval in periods 2 and 4.

Table 8 shows the correlation coefficient for the time spent on rumination periods in intermeal interval and the time spent on meals that preceded and followed rumination period. The correlation coefficient between time spent

Table 6. Length of rumination period and interval length between rumination period

\begin{tabular}{|c|c|c|}
\hline & Average & S.E. ${ }^{1)}$ \\
\hline \multicolumn{3}{|c|}{ Length of rumination periods (min.) } \\
\hline Period 1 ( $8: 20 \sim 11: 19)$ & $22.1^{\mathrm{a}}$ & 1.9 \\
\hline Period $2(11: 20 \sim 17: 19)$ & $24.2^{5}$ & 1.6 \\
\hline Period $3(17: 20 \sim 20: 19)$ & $27.0^{\mathrm{a}}$ & 2.3 \\
\hline Period $4(20: 20 \sim 8: 19)$ & $33.2^{b}$ & 2.4 \\
\hline \multicolumn{3}{|l|}{ Interval length (min.) } \\
\hline Period 1 & 57.9 & 10.7 \\
\hline Period 2 & 48.0 & 2.7 \\
\hline Period 3 & 58.2 & 4.3 \\
\hline Period 4 & 44.6 & 3.1 \\
\hline \multicolumn{3}{|c|}{ Number of rumination periods } \\
\hline Period 1 & $0.7^{\mathrm{a}}$ & 0.1 \\
\hline Period 2 & 4. $1^{b}$ & 0.2 \\
\hline Period 3 & $0.7^{a}$ & 0.1 \\
\hline Period 4 & $8.6^{E}$ & 0.4 \\
\hline
\end{tabular}

Table 7. Correlation coefficient among meal length (M), pre- and post-meal interval lengths (MI) in each period

\begin{tabular}{|c|c|c|c|c|}
\hline \multirow[b]{2}{*}{ Periods } & \multicolumn{2}{|c|}{ MI } & \multirow{2}{*}{$\begin{array}{c}\mathrm{M} \\
\begin{array}{l}\text { Pre- and } \\
\text { post }-\mathrm{MI}\end{array}\end{array}$} & \multirow{2}{*}{$\begin{array}{l}\text { Number } \\
\text { of } \\
\text { samples }\end{array}$} \\
\hline & $\begin{array}{c}\text { Pre. } \\
\text { meal }^{1)}\end{array}$ & $\begin{array}{l}\text { Post. } \\
\text { meal }^{2)}\end{array}$ & & \\
\hline P 1 & +0.056 & +0.041 & +0.183 & 63 \\
\hline $\mathrm{P} 2$ & -0.027 & $+0.345^{*}$ & -0.202 & 54 \\
\hline P 3 & +0.108 & +0.155 & +0.239 & 43 \\
\hline $\mathrm{P} 4$ & +0.097 & $+0.494^{*}$ & -0.142 & 46 \\
\hline
\end{tabular}

1) Meals preceded the inter-meal intervals.

2) Meals followed the inter-meal intervals.

* Significant at the level of $5 \%$. 
Table 8. Correlation coefficient among the time spent on rumination periods (RT) in inter-meal interval and on meals (MT) that preceded and followed rumination periods in each period

\begin{tabular}{|c|c|c|c|c|}
\hline \multirow[b]{2}{*}{ Periods } & \multicolumn{2}{|c|}{ Rumination (RT) } & \multirow{2}{*}{$\begin{array}{l}\text { Meal (MT) } \\
\begin{array}{l}\text { Pre. and } \\
\text { post. RT }\end{array}\end{array}$} & \multirow{2}{*}{$\begin{array}{l}\text { Number } \\
\text { of } \\
\text { samples }\end{array}$} \\
\hline & $\begin{array}{l}\text { Pre } \\
\text { MT }^{\mathrm{l}}\end{array}$ & $\begin{array}{l}\text { Post. } \\
\text { MT }^{2)}\end{array}$ & & \\
\hline P 1 & $+0.578^{*}$ & +0.268 & +0.072 & 16 \\
\hline $\mathrm{P} 2$ & -0.071 & $+0.431^{*}$ & -0.064 & 22 \\
\hline P 3 & $+0.552^{*}$ & -0.276 & -0.064 & 16 \\
\hline P4 & -0.052 & $+0.506^{*}$ & -0.157 & 35 \\
\hline
\end{tabular}

1) Time spent for meals preceding ruminations.

2) Time spent for meals following ruminations.

* Significant at the level of $5 \%$.

on rumination periods and time spent on preceding meals was positive $(\mathrm{P}<0.05)$ in periods 1 and 3 , and that between rumination periods and the following meals was positive $(P<0.05)$ only in periods 2 and 4 . The correlation coefficient between time spent on meals that preceded and followed rumination was not significant in any period.

There are numerous reports on relationships between the duration of inter-meal interval and meal size (amount of intake per meal) or meal duration in rats and other non-ruminants ${ }^{5,12,15)}$. SLATER ${ }^{12)}$ concluded that the positive correlation between meal duration and post-meal interval was significant. LE MAGEN and Devos ${ }^{5)}$ also concluded that only post-meal interval length related to meal size in rats. Unlike results obtained in non-ruminant experiments ${ }^{5,12,15)}$, our results showed that meal length for ruminants was related to the premeal interval length. In ruminants, METz $z^{7)}$ indicated that meal length was only related to the pre-meal interval and he concluded that the relationship between meal duration and inter-meal interval in ruminants was different from non-ruminants. In our study, we also found that the time spent on meals was significantly influenced by the time spent on rumination periods in the pre-meal interval in periods 2 and 4 . These results indicate that meal length and the time spent on meals in- creased according to increasing rumination period after the onset of rumination activity (periods 2 and 4). We concluded that the time spent on meals was affected by the time spent on rumination periods in pre-meal intervals after the onset of rumination, and not before the onset of rumination activity.

It is suggested that if rumination periods were restricted by some factors and shortened time spent on rumination periods after the onest of rumination activities, the time spent on meals might be shorter. PEARCE ${ }^{8)}$ concluded that the diurnal rumination period pattern was affected by the feeding schedule (feeding time of concentrate and roughage). In this study, the time spent on meals and meal length increased, and time spent on rumination periods and length of rumination period decreased immediately after feeding. This indicated that the feeding schedule affected eating and rumination patterns. Therefore, feeding schedules may have affected feed intake. However, few studies on changes in eating patterns by altering feeding schedules have been conducted for ruminants. Investigations on the effect of feeding schedules on meal and rumination periods pattern are important for increasing the amount of roughage intake.

\section{References}

1) Chase, L.E., P.J. Wangsness and B.R. 


\section{MoRITA and Nishino}

BAUMGardT, Feeding behavior of steers fed a complete mixed ration. J. Dairy Sci., 59 : 19231928. 1976.

2) Forbes, J.M., Introduction, In The voluntary food intake of farm animals. 1-13. Butterworth. London. 1986.

3) Hayasaka, K, N. Takusari and N. Yamagishi, Effect of TMR frequency on eating behavior of lactating cows. Anim. Sci. Technol. (Jpn.), 62 : 692-694. 1991. (in Japanese)

4) HIDARI, H., Analysis of diural feeding pattern of sheep fed various feed in free access. Jap. J. Zoothech. Sci., 47 : 283-291. 1976.

5) Le Magen, J. and M. Devos, Metabolic correlates of the meal onset in the free food intake of rats. Physiol. Behav., 5 : 805-814. 1970.

6) Matsui, K., A quantification of jaw movements during grazing and rumination in free-ranging cattle by an ambulatory data-logger. Anim. Sci. Technol. (Jpn.), 63 : 1188-1194. 1992. (in Japanese)

7) MErz, J.H.M., Time patterns of feeding and rumination in domestic cattle. Med. Landbouwh. Wageningen, 75 : 1-66. 1975.

8) PeArce, G.R., Rumination in sheep. The circadian pattern of rumination. Aust. J. Agric. Res., 16 : 635-648. 1965.
9) Penning, G., G.L. Steel and R.H. Johnson, Further development and use of an automatic recording system in sheep grazing studies. Grass and Forage Sci., 39 : 345-351. 1984.

10) Peterson, A.D., B.R. Baumgard and T.A. Long, Relationship between intake of some forage and feeding behavior of sheep. J. Anim. Sci., 38 : 172-177. 1974.

11) Putnam, P.A. and R.E. Davis, Ration effects on drylot steer feeding patterns. J. Anim. Sci., 22 : 437-448. 1963.

12) SlATER, P.J.B., The temporal pattern of feeding in the Zebra Finch. Anim. Behav, $22: 506-515$. 1974.

13) STEEl, R.G.D. and J.H. TORRIE, Nonparametric statistics. In Principles and procedures of statistics: A biometrical approach. 533-553. McGraw-Hill Book Company. New York. 1980.

14) Wangness, P.J., L.E. Chase, A.D. Perterson, T. G. HARTSOCK, D.J. KELlMEL and B.R. BAUMGARDT, System for monitoring feeding behavior of sheep. J. Anim. Sci., $42:$ 1544-1549. 1976.

15) WiePKeMA, P.R., Behaviour changes in CBA mice as a result of one goldthioglucose injection. Behaviour, $32: 179-210.1968$. 


\title{
去勢牛における乾草自由採食時の採食期および 反忽期の定義ならびに採食と反忽の関連性
}

\author{
森田 茂・西埜 進
}

酪農学園大学, 江別市 069

\begin{abstract}
ホルスタイン種去勢牛（試験開始時体重的 $200 \mathrm{~kg}$ ）16 頭を供試し，以下の実驗を行なった。給与飼料 には, 市肘のペレット状配合飼料㧍よびイネ科主体 1 番刘乾草を用いた。配合飼料の乾物給与日量は代 謝体重 $\mathrm{kg}$ 当り $75 \mathrm{~g}$ とし, 乾草は自由採食させた。.いずれの飼料む，1日2回 $8: 20$ および $17 ; 20$ に給 与した。試験期間は 11 日間とし, その最終日にテレビカメラにより採食行動を調查した。同時に, 咬筋 の筋電図から反棃時間を調查した．代謝体重当りの乾草乾物採食量は, 約 $28 \mathrm{~g} /$ 日上なった．採食バウト および採食バウト間隔の持続時間分布から，前後に 4 分を超える採食活動の休止期が認められた場合

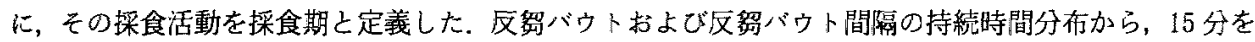
超える期間，反妿活動の休止が認められた場合，反哿期と定義した．1 日当りの採食時間（採食期の合計 時間）は約 4 時間，反鴐時間は約 7 時間亡なった。飼料給与後反鴐開始までの時間は，約 3 時間であっ た. 锢料給与 3 時間以降の期間では, 前の採食終了後, 次の採食開始までの時間が長い结ど，次の採食 期の持続時間は長くなること肪示された，飼料給与後 3 時間以内の期間に㧊いては，前の採食時間の延 長によりその後の反虫時閪が延長するのに対し，3時間以降の期間では, 反智時間の長さによりその後 の採食時間が影響を受けることが示された。
\end{abstract}

